Tropical Journal of Pharmaceutical Research February 2013; 12 (1): 77-84

ISSN: $1596-5996$ (print); 1596-9827 (electronic)

(c) Pharmacotherapy Group, Faculty of Pharmacy, University of Benin, Benin City, 300001 Nigeria.

All rights reserved.

Available online at http://www.tjpr.org

Original Research Article

http://dx.doi.org/10.4314/tjpr.v12i1.13

\title{
Addition of Selenium to Carica papaya Linn Pulp Extract Enhances Dermal Wound Healing Activity
}

\author{
Nafiu B Abdulrazaq, Haris B Akram, Dinie Najwa Bero, Mohd Yusof bin \\ Mohamad, Izzati Abd Malik and Mohammad Tariqur Rahman*
}

Department of Biomedical Science, Faculty of Science, International Islamic University Malaysia Jalan Istana, Bandar Indera Mahkota, Kuantan, Pahang 25200, Malaysia

*For correspondence: E-mail: tarique@iium.edu.my; Tel: +6095716 400 ext 2805; Fax: +6095716781

Received: 10 May 2012

Revised accepted: 3 January 2013

\begin{abstract}
Purpose: To investigate the combined effect of Carica papaya extract and mineral elements wound healing.

Methods: Phosphate-buffered saline (PBS) and water extracts of unripe Carica papaya. papaya were analyzed for mineral element composition (Ca, calcium; Mg, magnesium; Na, sodium; Fe, iron; Mn, manganese; Zn, zinc; Ag, silver; and Se, selenium) using a microwave-assisted digestion procedure. Atomic absorption spectrophotometry was used for the analysis of the elements. Phytochemical analysis was conducted using standard protocols. Mice weighing $25-30 \mathrm{~g}$ were anesthetized, shaved and inflicted with wound at the dorsal region using a biopsy punch. The mice were treated topically twice daily with or without $5 \mathrm{mg} / \mathrm{ml}$ PBS or water extracts containing 100 or $200 \mu \mathrm{M} Z \mathrm{Zn} 2+$ or 1.0 or 0.5 $\mu \mathrm{g} / \mathrm{g}$ Se2+. The standard (positive control) group was treated with solcoseryl and the negative control with deionised H2O. Wound area was monitored with a camera and evaluated by software.

Results: PBS extract formulated with Se2+. $(0.5$ or $1.0 \mu \mathrm{g} / \mathrm{g})$ took approximately 9 days for complete wound healing while negative control took 14 days and other treatment groups least 10 days. PBS extract contained $9 \%$ protein but no tannin while water extract contained $0.58 \%$ protein and tannins. Calcium (137.98 mg/100 g extract) constituted the most abundant macro-element while Se (32.14 $\mathrm{mg} / 100 \mathrm{~g}$ extract) was the most abundant microelement in C. papaya pulp.

Conclusion: Addition of selenium to C. papaya extracts augments the wound healing activity of the extracts.
\end{abstract}

Keywords: Papaya, Zn, Selenium, dermal wound healing

Tropical Journal of Pharmaceutical Research is indexed by Science Citation Index (SciSearch), Scopus, International Pharmaceutical Abstract, Chemical Abstracts, Embase, Index Copernicus, EBSCO, African Index Medicus, JournalSeek, Journal Citation Reports/Science Edition, Directory of Open Access Journals (DOAJ), African Journal Online, Bioline International, Open-J-Gate and Pharmacy Abstracts

\section{INTRODUCTION}

Carica papaya (L. Caricaceae) is a lactiferous plant, and produces latex rich in the enzymes, papain (a potent wound healing enzyme) and chymopapain [1]. These enzymes have antimicrobial and antioxidant properties [2,]. C. papaya has also been used in many parts of Africa for the treatment of burns, prevention of burns infections and de-sloughing necrotic tissue in wounds [1]. Traditional uses of papaya latex for wound healing have been confirmed and attributed to its content [3]. It is expected that any chemicals and/or natural bioactive components having either or both antioxidant and cell proliferative effects might have an influence on the wound healing process. Therefore, we have added Se, a well-known antioxidant and $\mathrm{Zn}$, a well-known cell proliferating element [4] to green papaya extract to determine if these added 
substances would enhance the wound healing healing properties of the extract.

Zinc $(\mathrm{Zn})$ is an important element in the wound healing process as it is a cofactor for the synthesis of structural components and plays an essential regulatory role in cellular function [4]. Se functions within the active site of the antioxidant enzymes, Oral or topical Se supplementation resulted in less skin damage after test mice were irradiated with UV rays, as indicated by reduced inflammation and pigmentation, and lower incidence of skin cancer. A similar study in female human volunteers yielded encouraging results [5].

\section{EXPERIMENTAL}

\section{Collection of papaya}

The green (unripe) fruits of Carica papaya of Exotica variety were collected during the month of July from a farm at Jabatan Pertanian Tanjung Malim, Perak, Malaysia. The size of the fruits collected were in the range of $15-20 \mathrm{~cm} \times 10-$ $12 \mathrm{~cm}$. The fruit was identified and authenticated by Dr Nurziana of Herbal Laboratory, Faculty of Pharmacy, International Islamic University Malysia (IIUM). A voucher specimen (no. Eiium 34) was deposited at the herbarium of the Faculty of Pharmacy, IIUM for future reference.

\section{Preparation of papaya extract}

The extract was prepared following the procedure of Anuar and colleagues [4] except that the pulp was used for wound healing studies while the peel and seed extracts were analysed only for mineral element composition. Briefly, the plant material was cut into small pieces and homogenized using either sterile phosphatebuffered saline (PBS) or sterile deionized water $\left(\mathrm{dH}_{2} \mathrm{O}\right)$, One part by weight of the pulp was added to 3 parts of solvent, crushed in a clean blender and transferred to an incubator shaker at $37^{\circ} \mathrm{C}$ for $8 \mathrm{~h}$. The mixture was then centrifuged at $200 \mathrm{~g}$ for $30 \mathrm{~min}$ at $4{ }^{\circ} \mathrm{C}$. The supernatant containing the extract was collected and freezedried to obtain the final extract. Either zinc (SYSTERM $^{\circledR}, 100$ or $200 \mathrm{mM}$ ) or selenium (Acros Organics, 0.5 or $1 \mu \mathrm{g}$ per $\mathrm{mg}$ of extract) dissolved in $\mathrm{dH}_{2} \mathrm{O}$ was added to either the water extract (WE) or PBS extract (PE). Both the weight of the pulp (without seeds) and that of the extract were recorded to determine yield.

\section{Evaluation of mineral composition of $C$. papaya}

This investigation was carried out on the elemental content of the seed, pulp and peel extracts of papaya. Both water and PBS extracts of Carica papaya seed, pulp and peel, prepared following the same method as explained in the section, "Preparation of papaya extract" above, were analysed to determine the concentrations of 8 mineral elements, namely: $\mathrm{Ca}, \mathrm{Mg}, \mathrm{Na}, \mathrm{Fe}, \mathrm{Mn}$, $\mathrm{Zn}, \mathrm{Ag}$, and Se using microwave-assisted digestion using nitric acid-hydrogen peroxide procedure [6] for sample preparation and atomic absorption spectrophotometry (AAS) for analysis. Briefly, $0.3 \mathrm{~g}$ of the sample was taken in a 100 $\mathrm{mL}$ Teflon vessel and digested with $6 \mathrm{ml}$ of $\mathrm{HNO}_{3}$ and $1 \mathrm{ml} \mathrm{H} \mathrm{H}_{2} \mathrm{O}_{2}$ in microwave digestion system. The temperature program was set at $240^{\circ} \mathrm{C}$ for $40 \mathrm{~min}$ with pressure of $60 \mathrm{bar}$ applied. The resulting solution was cooled and diluted to $50 \mathrm{ml}$ with deionized water. Analysis was carried out in triplicate.

\section{Phytochemical analysis of the extract}

Qualitative analysis of the phytochemical profile of both the PBS and water extracts" was carried out to determine the presence or absence of proteins, alkaloids, terpenoids, steroids, anthocyanin, flavonoids, saponins, tannins, while protein content was quantitatively determined.

\section{Protein analysis}

Bradford method was used to quantify proteins in the PBS and water extracts [7]. Briefly, the extract $(20 \mu \mathrm{L})$ was mixed together in a clear plastic $1 \mathrm{~mL}$ microcuvette with sodium chloride slution $(80 \mu \mathrm{L})$ and Bradford reagent $(1000 \mu \mathrm{L})$ and the absorbance was read at $595 \mathrm{~nm}$ wavelength. The resulting reading was compared to the standard solution of bovine serum albumin (Amresco ${ }^{\mathrm{TM}}$ ).

\section{Test for alkaloid (Dragendorff's test)}

The extract $(2 \mathrm{~mL})$ was mixed with a few drops of concentrated hydrochloric acid and a few drops of Dragendorff's reagent in a test tube. Colour change and precipitate formation (if any) were observed; a reddish brown precipitate indicated the presence of alkaloids [8].

\section{Test for terpenoids and steroids (Libermann- Burchard test)}

The extract $(2 \mathrm{ml})$ was mixed with 5 drops of acetic anhydride in a test tube and stirred to to mix well. Thereafter, 2 drops of concentrated sulphuric acid were added to the mixture by slow dripping down the test tube wall. Colour change and precipitate formation (if any) were observed. Formation of a brown ring at the junction of two 
layers with the upper layer turning green indicates the presence of steroids while formation of a deep red color indicates the presence of triterpenoids [9].

\section{Cyanidin test}

A piece of magnesium ribbon was dropped into a test tube containing $2 \mathrm{~mL}$ of extract, followed by a few drops of concentrated hydrochloric acid. The solution was allowed to mix and settle for 10 min. Colour change and precipitate formation (if any) were observed. A yellow precipate indicates the presence of anthocyanin [9].

\section{Tannin test}

The extract $(2 \mathrm{~mL})$ was mixed with a few drops of iron (III) chloride solution in a test tube, and colour change and precipitate formation (if any) were observed. Brownish green to blue-black precipitate was indicative of the presence of tannins in the sample [10].

\section{Test for saponin (Froth Test)}

The extract $(0.5 \mathrm{~g})$ was dissolved in $10 \mathrm{~mL}$ of distilled water. The test tube was closed with a stopper and shaken vigorously for $30 \mathrm{~s}$. The test tube was allowed to stand in a vertical position and observed over $30 \mathrm{~min}$. It was observed for the presence of "honey comb" froth above the surface of the liquid. Persistence of froth for over 30 min was indicative of the presence of saponin in the sample [9].

\section{Cardenolides (Keller Kiliani Test)}

The extract $(0.5 \mathrm{~g})$ was dissolved in $2 \mathrm{~mL}$ of glacial acetic acid containing one drop of ferric chloride solution and $1 \mathrm{~mL}$ of concentrated sulphuric acid was added. It was observed for the formation of a brown ring at the interface which is indicative of the presence of a deoxy sugar, a characteristic of cardenolides [8].

\section{Wound healing studies}

Female imprinting control region ICR mice (25 $30 \mathrm{~g}, 7$ - 8 weeks old, $\mathrm{n}=7$ ) were used to evaluate the effect of papaya extract alone and combined with $\mathrm{Zn}$ and Se on wound healing rate. The mice were purchased from Institute of Medical Research, Kuala Lumpur, Malaysia and housed under standard experimental conditions of $25 \pm 2{ }^{\circ} \mathrm{C}, 12 \mathrm{~h}$ light/dark cycle and fed on normal pellet diet and tap water ad libitum. A uniform circular epidermal wound was made at the dorsal part of the mice using a $6 \mathrm{~mm}$ biopsy puncher. Prior to incision, the mice were anesthetized using intraperitoneal administration of $6 \%$ Nembutal (Ceva Sante Animale ${ }^{\mathrm{TM}}, 0.1$ $\mathrm{mL} / 10 \mathrm{~g}$ of body weight). The skin was shaved, swabbed with alcohol pad and allowed to dry. The PBS and water extracts of papaya pulp ( 10 $\mu \mathrm{L})$ were applied twice a day. All animal handling and experimental procedures were approved by the institutional animal ethics committee (no. IIUM/305/20/4/10) and carried out in accordance with the Guidelines for the Care and Use of Laboratory Animals of the Faculty of Medicine, International Islamic University Malaysia (IIUM). Photos of the wounds from the first day of wound induction until the day of complete wound closure (CWC) were taken on alternative days to measure the rate of wound healing and the comparative wound healing efficiency of the extracts. A digital camera (Canon Powershot 5.0 MP) was used for the purpose. Photos were taken with the same settings of distance and aperture, and analyzed for wound surface area using Adobe \& CS3 Photoshop (Extended Version); the data were analyzed using SPSS for Windows version 16.0 software. Percent relative wound healing efficiency (RWHE) of the extracts was calculated to measure the rate of healing of the wound by the extracts compared with the time required for complete healing without any treatment (natural healing). RWHE (\%) was calculated according to Eq 1 .

$$
\begin{aligned}
& \text { RWHE }(\%)=\left\{\left(T_{N}-T_{E}\right) / T_{N}\right\} 100 \quad \ldots \ldots \ldots(1) \\
& \text { \% Relative Wound }=\frac{T_{N^{-}}}{T} \times
\end{aligned}
$$

where $T_{N}=$ time required for natural wound healing i.e., $C W C$ without any treatment and $T_{E}$ the time (number of days) taken to attain CWC for the treated group. In the current study, solcoseryl and a series of extracts were used: Negative control group was treated with sterile deionised water (NC); positive control group was treated with socoseryl (PC) The extract-treated groups were PBS extract (PE) alone, water extract (WE) alone, PBS or water extract plus $\mathrm{Zn}^{2+}(100 \mu \mathrm{M})$ or $\mathrm{Se}^{2+}(0.5 \mu \mathrm{g} / \mathrm{mg})$ (i.e., PEZ1 or WES1, respectively); and PBS or water extract plus $\mathrm{Zn}^{2+}(200 \mu \mathrm{M})$ or $\mathrm{Se}^{2+}(1.0 \mu \mathrm{g} / \mathrm{mg})$ (i.e., PEZ2 or WES2, respectively).

\section{Statistical analysis}

Statistical analysis was performed using the software SPSS version 17, and the data expressed as mean \pm SEM. One-way ANOVA was applied to the data followed by Tukey's posthoc test to assess mean differences between the groups at different time intervals. $P$ value was set at $p<0.05$. 


\section{RESULTS}

\section{Elemental composition of extracts}

The results (Figure 1) showed that $\mathrm{Ca}$ is the most abundant mineral element in all the parts of papaya analyzed with the highest content in the aqueous extract of the peel. Similarly, Se constituted the most abundant essential microelement with the highest level in FPE. The highest concentrations of $\mathrm{Na}, \mathrm{Mn}, \mathrm{Mg}$, Se, and $\mathrm{Zn}$ were found in FPE, SWE, FPE, FPE and FEW, respectively. Ag was not detected.

\section{Phytochemical characteristics of the extracts}

The extract yield of papaya fruit pulp was $6.70 \pm$ $0.02 \%(n=3)$ for the PBS extract and $9.10 \pm$ $0.10 \%(n=3)$. Mean protein content was $9.35 \pm$ 0.09 and $0.58 \pm 0.05 \%$ for the PBS and water extracts, respectively. Alkaloids were present in both the PBS and water extracts while tannins were present only in the water extract. All the other phytochemicals analyzed were absent from both extracts (Table 1).

\section{Effect of Se on papaya wound healing properties}

In the early stage of treatment (Days 0 - 4), reduction of the initial wound area ranged from 30 to $70 \%$ (Tables 2 and 3). By day 2, WE produced a significant $(p<0.05)$ reduction $(\sim 67$ $\%$ ) in wound area when compared to both NC (negative control) and PC (positive control) groups. Addition of $\mathrm{Se}^{2+}(0.5 \mu \mathrm{g} / \mathrm{mg})$ to PBS extract (PE) did not significantly influence $(p<$ 0.05 ) wound healing compared to positive control group. All other treatment groups showed significant reduction in wound area compared to $\mathrm{NC}$ but the reduction in wound areas were significantly $(p<0.05)$ lower compared to PC. At the end of the early stage of wound healing process (Day 4), all treated groups showed significant $(p<0.05)$ reduction in wound area compared to NC but the reduction was significantly $(p<0.05)$ lower than for PC except for the WE-treated group which showed no difference.

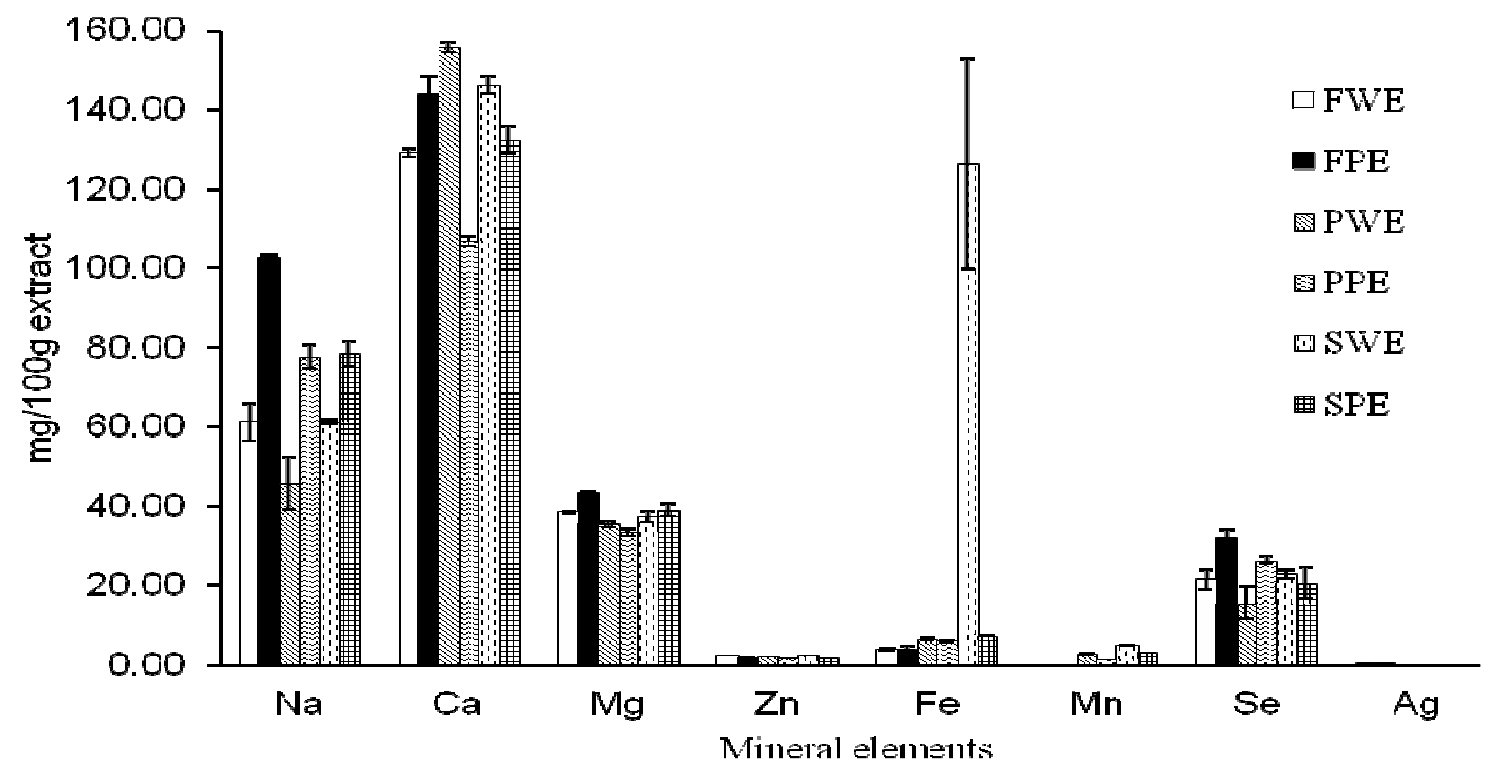

Figure 1: Mineral composition of $C$. papaya extracts. Key: Pulp water extract (FEW), Pulp PBS extract (FPE), Peel water extract (PWE), Peel PBS extract (PPE), seed water extract (SWE), and seed PBS extract (SPE)

Table 1: Yield and phytochemical profiles of the extracts

\begin{tabular}{|c|c|c|c|c|c|c|c|c|c|}
\hline Extract & 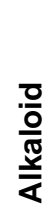 & 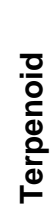 & $\begin{array}{l}\text { 음 } \\
\text { 일 } \\
\text { के }\end{array}$ & 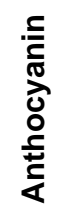 & 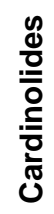 & $\begin{array}{l}\frac{5}{\bar{\delta}} \\
\frac{0}{\circ} \\
\text { ஸे }\end{array}$ & 兄 & $\frac{\text { 응 }}{\frac{0}{2}}$ & 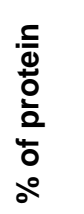 \\
\hline PBS extract (PE) & $\sqrt{ }$ & - & - & - & - & - & - & 6.7 & 9.35 \\
\hline Water extract (WE) & $\sqrt{ }$ & - & - & - & - & - & $\sqrt{ }$ & 9.2 & 0.58 \\
\hline
\end{tabular}


Table 2: Effect of topical treatment of wound with PBS extract of $C$. papaya containing $\mathrm{Zn}^{2+}$ and $\mathrm{Se}^{2+}$

\begin{tabular}{|c|c|c|c|c|c|c|c|}
\hline \multirow{2}{*}{ Day } & \multicolumn{7}{|c|}{ Reduction in wound area (\%) } \\
\hline & NC & PC & PE & PEZ1 & PEZ2 & PES1 & PES2 \\
\hline 0 & $0.00 \pm 0.00$ & $0.00 \pm 0.00$ & $0.00 \pm 0.00$ & $0.00 \pm 0.00$ & $0.00 \pm 0.00$ & $0.00 \pm 0.00$ & $0.00 \pm 0.00$ \\
\hline & $17.86 \pm 8.51^{\#}$ & $51.52 \pm 3.42^{*}$ & $42.20 \pm 2.71^{*}, \#$ & $41.97 \pm 3.92^{*}, \#$ & $20.29 \pm 5.42^{\#}$ & $51.55 \pm 2.70^{\star}$ & $44.18 \pm 6.24^{*}, \#$ \\
\hline 4 & $26.71 \pm 10.46^{\#}$ & $73.77 \pm 0.89^{*}$ & $69.93 \pm 0.69^{*}, \#$ & $61.91 \pm 4.88^{*}, \#$ & $46.76 \pm 3.94^{\star}, \#$ & $66.58 \pm 3.33^{*}, \#$ & $59.23 \pm 6.18^{*}, \#$ \\
\hline 6 & $39.78 \pm 12.12^{\#}$ & $85.45 \pm 2.23^{*}$ & $78.87 \pm 5.06^{\star}, \#$ & $86.13 \pm 2.59^{*}$ & $78.91 \pm 5.37^{*}, \#$ & $82.66 \pm 2.51^{\star}$ & $78.76 \pm 4.43^{\star}, \#$ \\
\hline 8 & $75.17 \pm 7.23^{\#}$ & $97.04 \pm 0.94^{*}$ & $93.03 \pm 5.67^{*}, \#$ & $97.31 \pm 0.83^{*}$ & $92.90 \pm 3.14^{*}, \#$ & $98.62 \pm 1.22^{*}$ & $98.99 \pm 0.63^{*}$ \\
\hline 10 & $88.97 \pm 3.74^{\#}$ & $99.51 \pm 0.32^{*}$ & $96.70 \pm 2.77^{*}$ & $99.77 \pm 0.09^{*}$ & $95.20 \pm 3.92^{*}, \#$ & $100.00 \pm 0.00^{*}$ & $100.00 \pm 0.00^{*}$ \\
\hline 12 & $94.35 \pm 2.69^{\#}$ & $100 \pm 0.00^{*}$ & $98.70 \pm 1.30^{*}$ & $100.00 \pm 0.00^{*}$ & $100.00 \pm 0.00^{*}$ & $100.00 \pm 0.00 *$ & $100.00 \pm 0.00^{*}$ \\
\hline 14 & $97.89 \pm 1.23$ & $100 \pm 0.00$ & $100.00 \pm 0.00$ & $100.00 \pm 0.00$ & $100.00 \pm 0.00$ & $0 \pm 0.00$ & .00 \\
\hline 16 & $100.00 \pm 0.00$ & $100 \pm 0.00$ & $100.00 \pm 0.00$ & $100.00 \pm 0.00$ & $100.00 \pm 0.00$ & $100.00 \pm 0.00$ & $100.00 \pm 0.00$ \\
\hline \multicolumn{8}{|c|}{ 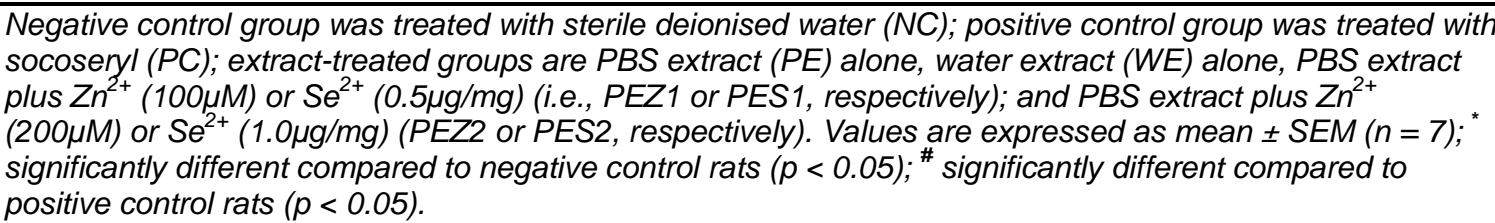 } \\
\hline
\end{tabular}

Table 3: Effect of topical treatment of wound with C. papaya water extract containing $\mathrm{Zn}^{2+}$ and $\mathrm{Se}^{2+}$

\begin{tabular}{|c|c|c|c|c|c|c|c|}
\hline \multirow[b]{2}{*}{ Day } & \multicolumn{7}{|c|}{ Reduction in wound area (\%) } \\
\hline & NC & $P C$ & WE & WEZ1 & WEZ2 & WES1 & WES2 \\
\hline 0 & $0.00 \pm 0.00$ & $0.00 \pm 0.00$ & $0.00 \pm 0.00$ & $0.00 \pm 0.00$ & $0.00 \pm 0.00$ & $0.00 \pm 0.00$ & $0.00 \pm 0.00$ \\
\hline 2 & $17.86 \pm 8.51^{\#}$ & $51.52 \pm 3.42^{*}$ & $67.37 \pm 8.81^{*}, \#$ & $42.43 \pm 6.22^{*}, \#$ & $29.64 \pm 7.43^{*}, \#$ & $36.39 \pm 5.36^{*}, \#$ & $27.18 \pm 8.19^{*}, \#$ \\
\hline 4 & $26.71 \pm 10.46^{\#}$ & $73.77 \pm 0.89^{*}$ & $71.23 \pm 1.89^{*}$ & $66.11 \pm 4.23^{\star}, \#$ & $55.97 \pm 3.92^{*}, \#$ & $54.10 \pm 4.12^{*}, \#$ & $47.66 \pm 5.23^{*}, \#$ \\
\hline 6 & $39.78 \pm 12.12^{\#}$ & $85.45 \pm 2.23^{*}$ & $81.50 \pm 3.86^{*}, \#$ & $87.30 \pm 2.62^{*}$ & $75.26 \pm 4.35^{\star}, \#$ & $84.90 \pm 2.83^{\star}$ & $74.65 \pm 4.94^{*}, \#$ \\
\hline 8 & $75.17 \pm 7.23^{\#}$ & $97.04 \pm 0.94^{*}$ & $97.00 \pm 0.42^{*}$ & $98.10 \pm 0.78^{\star}$ & $94.39 \pm 2.26$ & $97.30 \pm 0.77^{*}$ & $96.17 \pm 1.15^{\star}$ \\
\hline 10 & $88.97 \pm 3.74^{\#}$ & $99.51 \pm 0.32^{*}$ & $98.47 \pm 0.23^{*}$ & $99.87 \pm 0.09^{*}$ & $98.63 \pm 0.34^{*}$ & $99.53 \pm 0.32^{*}$ & $99.26 \pm 0.29^{*}$ \\
\hline 12 & $94.35 \pm 2.69^{\#}$ & $100 \pm 0.00^{*}$ & $99.17 \pm 0.56$ & $100.00 \pm 0.00 *$ & $99.47 \pm 0.25^{*}$ & $100.00 \pm 0.00$ & $100.00 \pm 0.00 *$ \\
\hline 14 & $97.89 \pm 1.23$ & $100 \pm 0.00$ & $99.80 \pm 0.20$ & $100.00 \pm 0.00$ & $99.90 \pm 0.10$ & $100.00 \pm 0.00$ & $100.00 \pm 0.00$ \\
\hline 16 & $100.00 \pm 0.00$ & $100 \pm 0.00$ & $100.00 \pm 0.00$ & $100.00 \pm 0.00$ & $100.00 \pm 0.00$ & $100.00 \pm 0.00$ & $100.00 \pm 0.00$ \\
\hline $\begin{array}{l}\text { WE } \\
\text { Val }\end{array}$ & nte expiffosse & S mean $\pm S E$ & $t(n=7) ;$; $^{*}$ signific & d water (NC); pc & mpared to neg & oup was treated & $\begin{array}{l}\text { vith socoseryl } \\
5 \mu \mathrm{m} / \mathrm{mg} \text { ) (i.e., } \\
\text { respectively). } \\
\text {.05); }\end{array}$ \\
\hline
\end{tabular}

By day 6, addition of $\mathrm{Zn}^{2+}(100 \mu \mathrm{M})$ or $\mathrm{Se}^{2+}(0.5$ $\mu \mathrm{g} / \mathrm{mg}$ ) to $\mathrm{PE}$ or WE did not significantly influence $(p<0.05)$ when compared to PC. Other treated groups produced significant reduction $(p<0.05)$ in wound area compared to $\mathrm{NC}$, although the reductions were less pronounced than by PC. By day 8 , all the treated groups showed no significant difference $(p<$ 0.05 ) in wound area compared to PC except for $\mathrm{Zn}^{2+}(200 \mu \mathrm{M}) / \mathrm{PE}$ and PE-treated groups. A similar result was obtained at the end of day 10 except that only $\mathrm{Zn}^{2+}(200 \mu \mathrm{M}) / \mathrm{PE}$ showed significantly higher healing property $(p<0.05)$ than PC. Furthermore, only PE containing $\mathrm{Se}^{2+}$ $(0.5$ or $1 \mu \mathrm{g} / \mathrm{mg}$ ) produced complete wound closure (Tables 2 and 3 ).

\section{Effect of addition of $\mathrm{Se}^{2+}$ to extract on wound healing}

When the wound was treated with PE containing Se, healing duration (CWC, $\sim 9$ days) was significantly shorter $(p<0.05)$ than for other groups. For the groups given either solcoseryl, $\mathrm{WE} / 100 \mu \mathrm{M} \mathrm{Zn}$ or WE/0.5 $\mu \mathrm{g} / \mathrm{mg}$ Se, CWC was 10 - 11 days while for the rest, wound healing was within 12 - 14 days. Compared to negative control group, all the treatment groups reduced significantly $(p<0.05)$ the duration for CWC. The most efficient healing (38\%), as determined RWHE, was observed in the PE/Se $(0.5 \mu \mathrm{g} / \mathrm{mg})$ (Table 2).

\section{DISCUSSION}

Papaya has been widely used for therapeutic purposes. The therapeutic effectiveness of green or raw papaya for medicinal purposes is perhaps related to its higher latex content compared with ripe papaya which has a reduced number of laticifer cells [11]. The latex of green papaya contains high amounts of protease group of enzymes namely, papain and chymopapain [1].

Some solvents have been used to extract various phytochemicals from papaya $[10,11$,$] .$ 
Table 4: Mean time (days) for complete wound healing

\begin{tabular}{|c|c|c|}
\hline Treatment/group & Time (days) & RWHE (\%) \\
\hline Negative control (NC) & $14.3 \pm 0.7$ & - \\
\hline Solcoseryl (PC) & $10.6 \pm 0.4^{*}$ & 26 \\
\hline PBS extract (PE) & $12.0 \pm 1.2^{*}$ & 16 \\
\hline Water extract (WE) & $14.0 \pm 1.2$ & 2 \\
\hline $\mathrm{PE}+\mathrm{Zn} 100 \mathrm{mM}$ & $11.1 \pm 0.6^{*}$ & 22 \\
\hline $\mathrm{PE}+\mathrm{Zn} 200 \mathrm{mM}$ & $12.0 \pm 0.1^{*}$ & 16 \\
\hline $\mathrm{PE}+0.5 \mu \mathrm{g} \mathrm{Se} / \mathrm{mg}$ of extract & $8.9 \pm 0.4^{*}, \bullet$ & 38 \\
\hline $\mathrm{PE}+1.0 \mu \mathrm{g} \mathrm{Se} / \mathrm{mg}$ of extract & $9.1 \pm 0.4^{\star}$ & 36 \\
\hline $\mathrm{WE}+\mathrm{Zn} 100 \mathrm{mM}$ & $10.6 \pm 0.4^{*}$ & 26 \\
\hline $\mathrm{WE}+\mathrm{Zn} 200 \mathrm{mM}$ & $12.9 \pm 0.7^{*}$ & 10 \\
\hline $\mathrm{WE}+0.5 \mu \mathrm{g} \mathrm{Se} / \mathrm{mg}$ of extract & $10.6 \pm 0.6_{\star}^{*}$ & 36 \\
\hline $\mathrm{WE}+1.0 \mu \mathrm{g} \mathrm{Se} / \mathrm{mg}$ of extract & $11.7 \pm 0.3^{*}$ & 18 \\
\hline
\end{tabular}

PBS and water were used as solvents in the present research and has also been used in the earlier study [3], because of its isotonic or physiological properties which aid in the extraction of protein-like bioactive compounds. The extraction temperature $\left(37^{\circ} \mathrm{C}\right)$ was selected for its importance as a physiological temperature and to avoid any possible denaturation of bioactive proteins in the extract which might be important for the wound healing. Tannins were detected in the extract prepared in the current study but neither saponins nor cardenolides were detected which were reportedly present in a previous study [12]. A probable reason for this difference could be different method of extraction, in which the aforementioned study used sun-dried raw papaya flesh while we used papaya flesh without drying. Another possible reason is the difference in papaya varieties used; the previous study used the Hawaiian Solo variety whereas we used the Exotica variety.

The mineral element composition of $C$. papaya has been analyzed in some studies but the results vary widely was and this has been attributed to differences in analytical methods, preparation and storage methods, varieties, place of cultivation, and parts of the fruit analyzed [13]. This, therefore, justifies the present study.

Mineral nutrients play an important role in wound healing. Fibroblasts and keratinocytes require optimal calcium signalling for cellular migration and differentiation leading to re-epithelization during the proliferative phase of wound healing $[14,15]$. Se, the most abundant micronutrient in C. papaya, is an essential cofactor for endogenous antioxidant enzymes which can reduce oxidative tissue damage resulting from neutrophil infiltration and microbial invasion of wounds [16].
During the early phase of wound healing (up to day 2), the water extract without $\mathrm{Zn}$ or $\mathrm{Se}$ exhibited the highest reduction in initial wound area; this effect was even higher than that obtained with the commercially available wound healing agent tested (solcoseryl) which served as positive control. However, the mean time required for complete wound closure (CWC) by the the water extract is longer than that of socoseryl. This indicates that the contents of the water extract might have contributed significantly during the early phase of wound healing but not in the latter phases such as tissue regeneration and re-modelling. Notably, the protein content in the water extract was significantly lower than that in the PBS extract. Moreover, the water extract contains tannins, unlike the PBS extract. On the whole, the PBS extract $(\mathrm{PE})$ required less time for the CWC than the water extract. This may be attributed to the higher protein content of PE which might have contributed to higher tissue regeneration, and hence, faster wound closure.

Addition of Se to PE has resulted in the shortest time to achieve CWC. Thus, both the higher protein content and Se might have contributed to the accelerated wound healing. $\mathrm{Zn}$ has been reported to aid the wound healing cascade, especially with regards to collagen and protein formation [5]. Inclusion of $\mathrm{Zn}$ in the water extract resulted in a shorter time to attain CWC than the water extract without the element. This may be causally linked to the cell proliferating effect of $\mathrm{Zn}$ and lower protein content of the water extract. $\mathrm{Zn}$ participates in the regulation of cell proliferation in several ways. It is essential to enzyme systems that influence cell division and proliferation [17]. Indeed, the exact mechanism and dynamics of collagen formation due to $\mathrm{Zn}$ added to extracts are yet to be determined. However, the addition of $\mathrm{Zn}$ to PE, which in itself has high protein content, did not cause further reduction in the time to achieve CWC. This is 
perhaps due to the fact that proliferative effect, either by $\mathrm{Zn}$ or any protein in the extract, might have reached a plateau. Additional proliferative effect might require other physiological responses such as antioxidant activity.

The addition of Se was designed to take advantage of its antioxidant properties which aid in the reduction of free radicals. This phenomenon is important when we consider that Se is an important component in the enzyme, glutathione peroxidase. The protein debriding mechanisms of papain and chymopapain when combined with the protein synthetic functions of $\mathrm{Zn}$ might have resulted in the zinc-containing extracts producing faster wound healing in the late phase. It is noted that none of the mice treated with papaya extracts resulted in either inflammation or pus formation. However, the mice treated with solcoseryl showed pus formation while the mice treated with sterile deionized water (NC) showed inflammation.

Generally, for all groups, the wounds were observed to still be 'fresh' on the first day, i.e., pinkish and moist, but turned to a darker colour (forming a scab) and seemed to be drier as the days went by. This was recognized as granulation tissue covered with epithelial cells. The phytochemical profiles of the extracts indicate that water as extracting solvent resulted in the extraction of tannins. Tannins are of special importance in the regulation of vascular endothelia growth factor (VEGF) expression [18] which in turn is responsible for angiogenesis and important for wound healing. The regulation of these growth factors is especially important in the proliferative stage of wound healing which probably explains why the water extract containing $100 \mu \mathrm{M}$ of $\mathrm{Zn}$ resulted in faster wound healing than PBS extract.

The re-modeling phase is the phase in which the collagen replacement occurs. Collagen formation is important as it increases the local tensile strength of the newly-formed skin. This is where it is noted that the zinc/extract treatment groups picked up speed as it has been stated that $\mathrm{Zn}$ is responsible for collagen and protein synthesis [5]. Although the Se/extract groups showed faster wound healing overall, they reached this phase slower than the Zn/extract groups but managed to close this gap.

\section{CONCLUSION}

Green papaya fruit extract reduced the healing time of dermal wounds in mice. The addition of $\mathrm{Se}$, in contrast to $\mathrm{Zn}$ addition, decreased healing time. Thus, incorporation of Se in green papaya fruit extract should be considered a potential therapeutic intervention for wound healing.

\section{REFERENCES}

1. Starley IF, Mohammed P, Schneider G, and Bickler SW. The treatment of paediatric burns using topical papaya. Burns 1999; 25: 636-639.

2. Osato JA, Santiago LA, Remo GM, Cuadra MS, Mori A. Antimicrobial and antioxidant activities of unripe papaya. Life Sci 1993; 53: 1383-1389.

3. Anuar NS, Zahari SS, Taib IA, Rahman MT. Effect of green and ripe Carica papaya epicarp extracts on wound healing and during pregnancy. Food Chem. Tox 2008; 46: 2384-2389.

4. Lansdown ABG, Mirastschijski U, Stubbs N, Scanlon E, Ågren MS., Zinc in wound healing: Theoretical, experimental, and clinical aspects. Wound Repair and Regeneration 2007; 15: 2-16.

5. Burke KE, Burford RG, Combs GF, Jr French IW, Skeffington DR. The effect of topical Lselenomethionine on minimal erythema dose of ultraviolet irradiation in humans. Photodermatol. Photoimmunol. Photomed 1992; 9: 52-57.

6. Mário HG, Gilberto BS, Regina VO, Lucimara AF, Joaquim AN, Ana Rita AN. Microwave-assisted digestion procedures for biological samples with diluted nitric acid: Identification of reaction products. Talanta 2009; 79: 396-401

7. Bradford MM. A rapid and sensitive method for the quantitation of microgram quantities of protein utilizing the principle of protein-dye binding. Anal. Biochem 1976; 72: 248-254.

8. Sofowora EA. Medicinal Plants and Traditional Medicine in Africa. John Wiley, Chichester, 1982; 256.

9. Trease GE, Evans WC. A Text Book of Pharmacognosy. ELSB Baillere Tindal, Oxford, 1987; 1055.

10. Martin J, Martin M. Tannin assays in ecological studies: lack of correlation between phenolics, proanthocyanidins and protein-precipitating constituents in mature foliage of six oak species. Oecologia 1982; 54(2): 205-211.

11. OECD (Environment Directorate Joint Meeting of the Chemicals Committee and the Working Party on Chemicals, Pesticides and Biotechnology). Consensus Document on the Biology of Papaya (Carica papaya) Series on Harmonisation of Regulatory Oversight in Biotechnology. 2005; No. 33.

12. Oloyede OI. Chemical Profile of Unripe Pulp of Carica papaya. Pak J Nutr 2005; 4: 379-381

13. Arturo H, Carmen R, Alejandro B, Macrina MM, Roberto A. Mineral composition of the papaya (Carica papaya variety sunrise) from Tenerife island. Eur Food Res Technol 2001; 212: 175-181

14. Leigh IM, Purkis PE, Whitehead $P$, Lane EB. Monospecific antibodies to keratin 1 carboxyterminal (synthetic peptide) and to keratin 10 as markers of epidermal differentiation. Br J Dermatol 1993; 129: 110-119

15. Zia $S$, Ndoye $A$, Lee $T X$, Webber RJ, Grando SA. Receptor-mediated inhibition of keratinocyte migration by nicotinic acid modulation of calcium flux and intracellular concentration. J Pharmacol Sci 2000; 293: 973-981.

16. Sengupta A, Lichti UF, Carlson BA, Ryscavage AO, Gladyshev VN, Yuspa SH, et al. Selenoproteins Are Essential for Proper Keratinocyte Function and Skin Development. PLoS ONE 2010; 5(8): e12249. doi:10.1371/journal.pone.0012249

17. MacDonald RS. The role of zinc in growth and cell proliferation. J Nutr 2000; 130(14): 1500S-1508S.

18. Khanna $S$, Venojarvi $M$, Roy $S$, Sharma $N$, Trikha $P$, Bagchi D, Bagchi $M$, Sen CK. Dermal wound 
Abdulrazaq et al

healing properties of redox-active grape seed proanthocyanidins. Free Rad Biol Med 2002; 33:

1089-1096. 